Review Article

\title{
Comparative effectiveness of vaccines for tuberculosis in endemic countries: a systematic review and meta-analysis
}

\begin{abstract}
Tuberculosis is a highly contagious disease (global 50\% prevalence), especially in lowresource areas where adequate treatment is limited. No current vaccine has shown efficacy after infancy.

Objectives: The primary outcome was to determine if newly available vaccines were effective in providing immunity from morbidity associated with Tuberculosis. The protocol for this review is published on Prospero and can be located by using the following record number, CRD42015017238.

Search methods: Searches of the Cochrane Library, Trip Database, PDQ-Evidence, PubMed, and Science Direct were completed. The search included common terms related to vaccine effectiveness and safety for tuberculosis.

Selection criteria: Randomized controlled trials comparing tuberculosis vaccines with placebo, in adults and children were screened for eligibility for compliance with inclusion criteria.

Data collection and analysis: Clinical outcomes data were reported for adverse events, safety and immunogenicity endpoints with $95 \%$ confidence intervals (CI). Vaccine efficacies were reported however, none of the vaccines in this review achieved an efficacy rate higher than $17.3 \%$ (95\% CI -31.9 to 48.2). Cytokine CD4 cell expression was observed.

Main results: This review includes 7 group comparisons with data from 5 clinical trials. There was significant heterogeneity between studies with respect to study population size, testing validation methods, and baseline characteristics. There was also considerable statistical heterogeneity (I2 $=75.3 \%$ ). None of the included studies demonstrated efficacy or effectiveness against Tuberculosis, the highest efficacy rate being $17.3 \%$ (95\% CI -31.9 to 48.2). Positive Quantiferon conversion was observed at a rate of (RR, 2.72 95\% CI 0.94, 7.85). Cytokine Positive CD4 T-cell expressing IFN-y growth was observed (Std. Mean Diff $1.9295 \%$ CI 1.19 to 2.65 ) in 4 studies. There is potential in the tolerability of the vectors explored in this review possess to be potential delivery pathways for future vaccines in this disease area.
\end{abstract}

Keywords: Tuberculosis vaccine, BCG, MVA85A, IC31, SATVI, TB vaccine review
Volume 3 Issue I - 2016

\author{
Nnamdi Nwachukwu, 'Tifa Kazadi \\ 'University of Oxford, UK
}

${ }^{2}$ Tifa Kazadi, USA

Correspondence: Nnamdi Nwachukwu, University of Oxford, Washington, DC, USA, Tel (6I7) 895-7605,

Email nnamdi.nwachukwu@kellogg.ox.ac.uk

Received: August 27, 2015 | Published: November 09, 2016
Abbreviations: $\mathrm{BCG}$, bacille calmette-guerin vaccine; CI, confidence interval; CD4, CD8, a type of white blood cell help to defend the body from infections; DNA, deoxyribonucleic acid; EPI, expanded program on immunizations; GAVI, global alliance for vaccines and immunization; HIV, human immunodeficiency virus; IAVI, international aids vaccine initiative; IFN, inteferon; LMIC, low to middle income countries; MDR-TB, multi-drug resistant tuberculosis; PATH, program for appropriate technology in health; QFT, quantiferon; RR, risk ratio; SABIN, sabin vaccine institute; SATVI, south african tuberculosis vaccine initiative; Std, standard; $\mathrm{TB}$, tuberculosis; WHO, world health organization; XDR-TB, extremely drug-resistant tuberculosis

\section{Introduction}

Tuberculosis is a highly contagious disease which currently has a standard of care which presents side effects which rival the symptoms of the disease it is targeted to prevent. The current treatment regimen for TB consists of four drugs (isoniazid, rifampin, pyrazinamide and ethambutol-for 2months, followed by 4 months of isoniazid and rifampin) which are delivered in tablet form, in most countries. Treatment regimens for more complicated forms of the disease can involve an elevated number of drugs as well as an extended duration of treatment. Due to the high probability of relapse, disease acceleration, and drug resistance monitored treatment periods have become the standard. These factors complicate addressing infected patients and successful treatment, especially in low-resource areas where adequate treatment may not be available. ${ }^{1}$ The current standard of care, the Bacillus Calmette-Guerin (BCG) vaccine, is the oldest vaccine in current use in the world. This vaccine been administered throughout the developed and developing world for tuberculosis in all countries, except for the United States and Netherlands, since the 1960s. ${ }^{2}$ Despite the clinical evidence that supports the wide administration of the BCG vaccine, the side effects associated with this vaccine present the patient with a difficult decision; take a vaccine which possesses potential adverse events such as; reversion to an infectious bacterial state, wildly differing strains resulting in no increased immunity, topical lesions at injection sites, and in severe cases, outbreaks of lymphadenitis have occurred when a new strain of BCG was introduced. ${ }^{1}$ There are many simultaneous efforts in different parts of the world to develop a vaccine which can provide immunity with an improved quality of life for the patient post immunization. Continuous 7 evaluations of ongoing efforts to identify a solution is necessary 
for collective advancements in the vaccine research community. From an ethical perspective, any current trials which are evaluating technologies which have been determined to be ineffective, or found to expose participants to unnecessary level of risk could be stopped if certain endpoints were reached in other trials. Vaccines solutions for neglected diseases are a global effort. Systematic reviews are a useful tool in determining whether an evaluation of an intervention should be explored or abandoned.

\section{Objectives}

The aim of this review is to determine if any of the vaccines that have been developed in the last two years are viable vaccine candidates for preventative immunization against $\mathrm{TB}$ in $[\mathrm{P}]$ disease naïve patients, who experience onset of tuberculosis in endemic countries (these countries will be identified using criteria established by WHO for high TB burden countries). These populations are concentrated in sub-Saharan Africa, Eastern Europe, Central Asia and Western South America.IThe prospective vaccine candidates will be evaluated against [C] Bacille Calmette-Guerin, also known as the BCG vaccine, which is the current standard of care in use for countries where tuberculosis is endemic. This vaccine is usually administered shortly after birth. [O] The primary outcome is to determine if newly available vaccines are effective in providing immunity from morbidity associated with Tuberculosis (protection in presence of disease in a clinical setting). The results of this review will be used to identify vaccines and/or viable approaches and methodologies which indicate promise of improving immunization to Tuberculosis. The protocol for this review is published on Prospero and can be located by using the following record number, CRD42015017238 $3-20$ (Tables 1-16) (Figures 1-3).

Table I Characteristics of Included Studies:Table I.Aeras-402 Tameris et al., ${ }^{3}$

\begin{tabular}{|c|c|}
\hline Methods & $\begin{array}{l}\text { Multi-center, double-blind, randomized, placebo-controlled, The primary outcome was safety, and included all solicited, unsolicited } \\
\text { and serious adverse events in all participants who received at least one dose of study vaccine. The percentage of participants with } \\
\text { AEs was presented by MedDRA Preferred Term. For categorical data, analysis was performed using the Chi-square test; and for AE } \\
\text { grading analysis the Chi-square test for linear trend was used. Statistical significance was assigned to } p \leq 0.05 \text {. }\end{array}$ \\
\hline Participants & $\begin{array}{l}\text { Infants were eligible for enrolment only if the parent or legal guardian provided written informed consent. We enrolled healthy } \\
\text { infants, aged I6-26 weeks, who had received BCG more than } 3 \text { months prior to randomization, who had received appropriate } \\
\text { routine immunizations at least I } 4 \text { days before randomization, and whose mother's HIV status was known. HIV-uninfected infants of } \\
\text { HIV-infected mothers were eligible. }\end{array}$ \\
\hline Interventions & An adenovector encoding a fusion protein of Mycobacterium tuberculosis antigens $85 \mathrm{~A}, 85 \mathrm{~B}$, and TBI 0.4 \\
\hline Outcomes & $\begin{array}{l}\text { The primary outcome was safety, and included all solicited, unsolicited and serious adverse events in all participants who received } \\
\text { at least one dose of study vaccine. Dose-finding and Immunogenicity }\end{array}$ \\
\hline Notes & $\begin{array}{l}\text { The quality control had significant issues meeting quality standards and was forced to abandon the primary efficacy endpoint due } \\
\text { to difficulty concerning the validity of clinical lab data. }\end{array}$ \\
\hline
\end{tabular}

Table 2 Risk of Bias (Aeras-402 Tameris et al., ${ }^{3}$

\begin{tabular}{ll}
\hline Bias & Author's \\
\hline $\begin{array}{l}\text { Random Sequence Generation } \\
\text { (Selection Bias) }\end{array}$ & Low Risk
\end{tabular}

Allocation Concealment (Selection Bias)

Blinding of Participants and Personnel (performance bias) Low Risk

Blinding of Outcome
Assessment (detection bias) Unclear Risk
Incomplete Outcome Data
(attrition bias)
$\begin{aligned} & \text { Selective Reporting (reporting } \\ & \text { bias) }\end{aligned}$

Other bias $\quad$ Unclear Risk

\section{Support for Judgment}

Infants were randomized to receive two intramuscular doses ofAERAS-402 or placebo on study days 0 and 28 using a paper-based system in Groups I-3 and an interactive voice response system (IVRS) in Groups 4-5.

Group allocation was sequential, subsequent to Data Monitoring Committee (DMC) review of safety data. Dose selection for Group 5 was determined by sponsor review of cumulative safety and immunogenicity data for Groups I-4 and all previous trials ofAERAS-402 in both adults and infants. ${ }^{11-13}$ The selection of the highest dose strength, I $\times$ I0I Ivp, was based on these data and supported by the protocol which states that in case of ambiguous data the highest dose should be selected.

Participants' parents or legal guardians and all clinical study staff were blinded to the assigned intervention group. Randomization in Groups I-3 was in a 3:I ratio (AERAS- 402: placebo),Group 4 in a I:I:I:I ratio to receive one of three dose levels ofAERAS-402 (I.5 × 1010, $3.0 \times 1010$, or I × I0II viral particles $(v p))$ or placebo, and Group 5 in a I:I randomization ratio $(I \times 101$ Ivp: placebo).

No Information Provided

No Information Provided

No Information Provided

The trial was funded by Aeras, the manufacturer of the vaccine candidate MVA85A, one of the clinical sites was SATVI. 3 of the 5 trials utilized this site. Same lead author as MVA85A Tameris et al., ${ }^{3}$

Table 3 Characteristics of Included Studies: $\mathrm{HI} / / \mathrm{C} 3$ I Reither et al., ${ }^{4}$

HIV-infected adults with CD4+ T cell counts. $350 / \mathrm{mm} 3$ and without evidence of active tuberculosis were enrolled and

Methods

$\mathrm{HIV}$-infected adults with CD4+ T cell counts. $350 / \mathrm{mm} 3$ and without evidence of active tuberculosis were enrolled and
followed until day 182 . $\mathrm{HI} / \mathrm{IC} 3 \mathrm{I}$ vaccine or placebo was randomly allocated in a $5: 1$ ratio. The vaccine was administered intramuscularly at day 0 and 56 . Safety assessment was based on medical history, clinical examinations, and blood and urine testing. Immunogenicity was determined by a short-term whole blood intracellular cytokine staining assay. 
Table Continued...

Participants

Interventions

Outcomes

Notes
Participants were eligible if they were between 18 and 55 years of age, HIV infected with CD4+ lymphocyte counts greater than $350 / \mathrm{mm} 3$, antiretroviral therapy naive, generally healthy, had no evidence of active TB, had no history of receiving immunosuppressive medication, immunoglobulins, blood products or known hypersensitivity to any of the vaccine components. Women of child bearing potential were eligible if pregnancy was excluded and they agreed to use at least two forms of acceptable contraception from 21 days prior to administration of the study vaccine through to the end of the study.

The Hybrid I (HI) vaccine is a recombinant fusion protein of the antigens Ag85B and ESAT-6 (Ag85B-ESAT-6), developed and manufactured by the Statens Serum Institut (Denmark). The adjuvant IC3I was developed by Intercell AG (Austria) and consists the cationic poly-amino acid KLK, which is composed of the amino acids lysine (K) and leucine (L), and ODNIa, a single stranded oligodeoxynucleotide with alternating sequences of the nucleic acids inosine and cytidine. A volume of $0.5 \mathrm{~mL}$ was administered providing a dose of $50 \mathrm{mg}$ Ag85B-ESAT6 (antigen) and $500 \mathrm{nmol} \mathrm{KLK}+20 \mathrm{nmol}$ ODNIa (adjuvant) or $0.5 \mathrm{~mL}$ Tris buffer (placebo).

HI/IC3I was well tolerated and safe in HIV-infected adults with a CD4+ Lymphocyte count greater than 350 cells/mm3. The vaccine did not have an effect on CD4+ T cell count or HIV-I viral load. HI/IC3I induced a specific and durable Th I immune response

The quality control had significant issues meeting quality standards and was forced to abandon the primary efficacy endpoint due to difficulty concerning the validity of clinical lab data.

Table 4 Risk of Bias (HI/IC3I Reither et al., ${ }^{4}$

\begin{tabular}{|c|c|}
\hline Bias & Author's Ju \\
\hline Random Sequence Generation (Selection Bias) & Low Risk \\
\hline Allocation Concealment (Selection Bias) & Low Risk \\
\hline $\begin{array}{l}\text { Blinding of Participants and Personnel } \\
\text { (performance bias) }\end{array}$ & Low Risk \\
\hline \multicolumn{2}{|c|}{ Blinding of Outcome Assessment (detection bias) Unclear Risk } \\
\hline Incomplete Outcome Data (attrition bias) & Unclear Risk \\
\hline Selective Reporting (reporting bias) & Unclear Ris \\
\hline
\end{tabular}

\section{Support for Judgment}

Participants were randomly allocated in a 5:I ratio to receive either $\mathrm{HI} / \mathrm{IC} 3$ I vaccine or placebo according to a pharmacist prepared the vaccination according the pre-prepared study randomization list.

Participants were randomly allocated in a 5:I ratio to receive either $\mathrm{HI} / \mathrm{IC} 3 \mathrm{I}$ vaccine or placebo according to a computer-generated randomization list. The pharmacist prepared the vaccination according the pre-prepared study randomization list.

The study monitors, investigators, and participants were blinded to study product. The study pharmacists prepared the investigational product. Syringes were masked with red tape in order to conceal a slight difference in the appearance of the $\mathrm{HI} / \mathrm{IC} 3 \mathrm{I}$ and placebo.

No Information Provided

No Information Provided

No Information Provided

Ingrid Kromann, Peter Bang, and Søren T. Hoff are employed by the Statens Serum Institut, a Danish not-for-profit governmental research institution which holds intellectual property rights on $\mathrm{HI}$ as a vaccine construct. Peter Andersen is a co-inventor on a patent application covering the use of $\mathrm{HI}$ as a vaccine (Patent No.WO9844I 19; Nucleic acid fragments and polypeptide fragments derived from M. tuberculosis). All rights have been assigned to Statens Serum Institut. The patent does not alter the authors' adherence to PLOS ONE policies on sharing data. This study also used SATVI as a clinical site 3 of 5 studies.

Table 5 Characteristics of Included Studies: MVA85A Ndaiye et al., ${ }^{5}$

\begin{tabular}{ll}
\hline Methods & We did a randomized, double-blind, placebo-controlled, phase 2 trial of MVA85A in adults infected with HIV-I, at \\
two clinical sites, in Cape Town, South Africa and Dakar, Senegal. \\
Eligible participants were aged I $8-50$ years, had no evidence of active tuberculosis, and had baseline CD4 counts \\
greater than 350 cells per $\mu \mathrm{L}$ if they had never received antiretroviral therapy or greater than 300 cells per $\mu \mathrm{L}$ (and \\
with undetectable viral load before randomization) if they were receiving antiretroviral therapy; participants with \\
latent tuberculosis infection were eligible if they had completed at least 5 months of isoniazid preventive therapy, \\
unless they had completed treatment for tuberculosis disease within 3 years before randomization. \\
Participants \\
The modified vaccinia virus Ankara expressing the major M tuberculosis antigen $85 A$ (MVA85A) is a clinically \\
advanced candidate vaccine. I0-I2 MVA85A is well tolerated and immunogenic in adults infected and not infected \\
with HIV-I, and in infants not exposed to HIV-I.I0-I4 MVA85A adds to BCG-induced protection against \\
mycobacterial challenge in some preclinical animal models. \\
Interventions \\
Tuberculosis disease endpoint I was defined as culture or GeneXpert MTB/RIF positivity; endpoint 2 included \\
endpoint I and a composite clinical endpoint (which included a single acid-fast bacilli smear from a sterile body \\
site; two smears from pulmonary and gastric sampling, and compatible clinical symptoms and radiological signs); and \\
endpoint 3 was participant commencement on anti-tubercular chemotherapy (see the study protocol for more \\
information; appendix). The M tuberculosis infection endpoint was defined as conversion from negative QFT at \\
baseline to positive QFT at the final visit. \\
N/A
\end{tabular}

Citation: Nwachukwu N, Kazadi T. Comparative effectiveness of vaccines for tuberculosis in endemic countries: a systematic review and meta-analysis. Int J Vaccines Vaccin. 20 I 6;3(I): I I-12. DOI: I0.15406/ijvv.2016.03.00057 
Table 6 Risk of Bias (MVA85A Ndaiye et al., 5

\begin{tabular}{|c|c|c|}
\hline Bias & Author's Judgment & Support for Judgment \\
\hline $\begin{array}{l}\text { Random Sequence } \\
\text { Generation } \\
\text { (Selection Bias) }\end{array}$ & Low Risk & $\begin{array}{l}\text { Participants were randomly assigned }(I: I) \text { in blocks of four by randomly generated } \\
\text { sequence to receive two intradermal injections of either MVA85A or placebo. } \\
\text { Randomization was stratified by antiretroviral therapy status and study site. }\end{array}$ \\
\hline $\begin{array}{l}\text { Allocation Concealment } \\
\text { (Selection Bias) }\end{array}$ & Low Risk & $\begin{array}{l}\text { Participants, nurses, investigators, and laboratory staff were masked to group } \\
\text { allocation. } \\
\text { Participants were randomly assigned }(\mathrm{I}: \mathrm{I}) \text { in blocks of four by a randomly }\end{array}$ \\
\hline $\begin{array}{l}\text { Blinding of Participants and Personnel } \\
\text { (performance bias) }\end{array}$ & Low Risk & $\begin{array}{l}\text { generated sequence of participant identification numbers via an interactive voice } \\
\text { response system to receive two intradermal injections of either } 1 \times 10^{8} \mathrm{pfu} \\
\text { MVA85A or placebo (Candida skin test antigen [Candin], Allermed Laboratories, } \\
\text { San Diego, CA, USA). }\end{array}$ \\
\hline $\begin{array}{l}\text { Blinding of Outcome } \\
\text { Assessment (detection bias) }\end{array}$ & Unclear Risk & No Information Provided \\
\hline Incomplete Outcome Data (attrition bias) & Unclear Risk & No Information Provided \\
\hline $\begin{array}{l}\text { Selective Reporting } \\
\text { (reporting bias) }\end{array}$ & Unclear Risk & No Information Provided \\
\hline Other bias & Unclear Risk & $\begin{array}{l}\text { HM was previously a shareholder in the Oxford-Emergent Tuberculosis } \\
\text { Consortium (OETC), a joint venture established for the development of } \\
\text { MVA85A (OETC no longer exists). KH has a patent (US } 5736524 \mathrm{~A} \text { ) related } \\
\text { to the development of a DNA vaccine against Mycobacterium tuberculosis. } \\
\text { RJW received grants from the European \& Developing Countries Clinical } \\
\text { Trials Partnership, the Welcome Trust, the UK Medical Research Council, and } \\
\text { the European Union during the conduct of the study, and personal fees from } \\
\text { GlaxoSmithKline unrelated to this work. The study was funded by the European } \\
\text { \& Developing Countries Clinical Trials Partnership (IP.07.32080.002), Aeras, Bill \& } \\
\text { Melinda Gates Foundation, the Wellcome Trust (095780, 084323, and 0883 I6), and } \\
\text { the Oxford-Emergent Tuberculosis Consortium. Quintiles (Bloemfontein, South } \\
\text { Africa) were used for the statistical analysis, and Aeras paid for this service. }\end{array}$ \\
\hline
\end{tabular}

Table 7 Characteristics of Included Studies: MVA85A Tameris et al.,3

In our double-blind, randomized, placebo-controlled phase $2 b$ trial, we enrolled healthy infants (aged 4-6 months) without HIV infection who had previously received BCG vaccination. We randomly allocated infants (I:I), according to an independently generated sequence with block sizes of four, to receive one intradermal dose of MVA85A or an equal volume of Candida skin test antigen as placebo at a clinical facility in a rural region near Cape Town, South Africa. We actively followed up infants every 3 months for up to 37 months. The primary study outcome was safety (incidence of adverse and serious adverse events) in all Methods vaccinated participants, but we also assessed efficacy in a protocol-defined group of participants who received at least one dose of allocated vaccine. The primary efficacy endpoint was incident tuberculosis incorporating microbiological, radiological, and clinical criteria, and the secondary efficacy endpoint was M tuberculosis infection according to QuantiFERON TB Gold In-tube conversion (Cellestis, Australia). This trial was registered with the South African National Clinical Trials Register (DOH-270109-2654) and with ClinicalTrials.gov on July 31, 2009, number NCT00953927

We enrolled healthy infants, aged 4-6 months and who had received BCG (Danish I33I, Statens Serum Institut, Denmark) within 7 days of birth. Infants had to have received all age-appropriate routine immunizations, and two doses of pneumococcal

Participants conjugate vaccine at least 28 days before study vaccination (amended to 14 days during enrolment). All infants had to be HIV ELISA negative, QuantiFERON-TB Gold In-tube test (QFT; Cellestis, Australia) negative, and have had no substantial exposure to a patient with known tuberculosis

MVA85A is a recombinant strain of modified Vaccinia Ankara virus expressing the immune-dominant $M$ tuberculosis protein, antigen 85A. MVA85A has been developed as a heterologous boost for BCG. Boosting BCG with MVA85A improved

Interventions BCG-induced protection against mycobacterial challenge in animals. MVA85A was well tolerated in clinical trials in infants. Furthermore, a BCG prime-MVA85A boost immunization regimen in infants induced antigen-specific ThI and ThI 7 cells, which are regarded as important in protection against tuberculosis.

Outcomes The primary safety outcome was incidence of adverse and serious adverse events. The primary efficacy outcome was incidence of endpoint. The secondary efficacy outcome was infection with M.Tuberculosis.

Notes N/A

Table 8 Risk of Bias (MVA85A Tameris et al., ${ }^{3}$

\begin{tabular}{|c|c|c|}
\hline Bias & Author's Judgment & Support for Judgment \\
\hline $\begin{array}{l}\text { Random Sequence Generation } \\
\text { (Selection Bias) }\end{array}$ & Low Risk & $\begin{array}{l}\text { In our double-blind, randomized, placebo-controlled phase } 2 \mathrm{~b} \text { trial, we enrolled } \\
\text { healthy infants (aged } 4-6 \text { months) without HIV infection who had previously } \\
\text { received BCG vaccination. We randomly allocated infants (I:I), according to } \\
\text { an independently generated sequence with block sizes of four, to receive one } \\
\text { intradermal dose of MVA85A or an equal volume of Candida skin test antigen } \\
\text { as placebo. }\end{array}$ \\
\hline
\end{tabular}


Table Continued...

\begin{tabular}{|c|c|c|}
\hline Bias & Author's Judgment & Support for Judgment \\
\hline $\begin{array}{l}\text { Allocation Concealment (Selection, } \\
\text { Bias) }\end{array}$ & Low Risk & $\begin{array}{l}\text { We randomly allocated infants in a I:I ratio, with a block size of four, by use of } \\
\text { an interactive voice/online response system to receive one intradermal dose } \\
\text { of MVA85A ( } 1 \times 10^{8} \text { plaque-forming units in } 0.06 \mathrm{~mL} \text { ) or an equal volume of } \\
\text { Candida skin test antigen (Candin, AllerMed, USA) as placebo. }\end{array}$ \\
\hline $\begin{array}{l}\text { Blinding of Participants and } \\
\text { Personnel (performance bias) }\end{array}$ & Unclear Risk & No Information Provided \\
\hline $\begin{array}{l}\text { Blinding of Outcome Assessment } \\
\text { (detection bias) }\end{array}$ & Low Risk & $\begin{array}{l}\text { Doses were prepared and labelled in masked syringes by an unmasked study } \\
\text { pharma cist. An independent statistician prepared the randomization schedule. } \\
\text { The parents or legal guardians of study participants, study staff administering } \\
\text { vaccinations or undertaking follow-up clinic assessments, and lab oratory staff } \\
\text { were masked to intervention group assignment. }\end{array}$ \\
\hline $\begin{array}{l}\text { Incomplete Outcome Data } \\
\text { (attrition bias) }\end{array}$ & Unclear Risk & $\begin{array}{l}\text { Exact figures were not provided, but stated that the number of participants lost } \\
\text { did not affect the final analysis }\end{array}$ \\
\hline $\begin{array}{l}\text { Selective Reporting (reporting } \\
\text { bias) }\end{array}$ & Unclear Risk & No Information Provided \\
\hline & & $\begin{array}{l}\text { SL and JES are employees of Emergent BioSolutions and own shares and } \\
\text { stock options in the company. HMcS is a shareholder in the Oxford-Emergent }\end{array}$ \\
\hline Other bias & Unclear Risk & $\begin{array}{l}\text { Tuberculosis Consortium (a joint venture between Emergent BioSolutions and } \\
\text { the University of Oxford). This study also used SATVI as a clinical site } 3 \text { of } 5 \\
\text { studies. Same lead author as Aeras- } 402 \text {. }\end{array}$ \\
\hline
\end{tabular}

Table 9 Characteristics of Included Stories: RUTI Nell et al., ${ }^{6}$

\begin{tabular}{|c|c|}
\hline Methods & $\begin{array}{l}\text { Double-blind, randomized, placebo-controlled Phase II Clinical Trial ( } 95 \text { patients randomized). Three different RUTI doses and } \\
\text { placebo were tested, randomized both in HIV-positive }(n=47) \text { and HIV-negative subjects }(n=48) \text {, after completion of one } \\
\text { month isoniazid }(\mathrm{INH}) \text { pre-vaccination. Each subject received two vaccine administrations, } 28 \text { Days apart. }\end{array}$ \\
\hline Participants & $\begin{array}{l}\text { Study inclusion criteria were men and women I } 8-50 \text { years of age, without evidence of active TB, positive tuberculin skin test } \\
(T S T+) \text { [ } 5 \mathrm{~mm} \text { induration] and Quantiferon TB Gold positive result. Additional inclusion criteria in the HIV-positive group were: } \\
\text { HIV antibody positive, CD4 count } 350 \text { cells } / \mathrm{mL} \text { and clinically stable subjects if on anti-retroviral treatment. }\end{array}$ \\
\hline Interventions & $\begin{array}{l}\text { The Hybrid I ( } \mathrm{HI} \text { ) vaccine is a recombinant fusion protein of the antigens Ag85B and ESAT-6 (Ag85B-ESAT-6), developed and } \\
\text { manufactured by the Statens Serum Institut (Denmark). The adjuvant IC3 I was developed by Intercell AG (Austria) and consists } \\
\text { the cationic poly-amino acid KLK, which is composed of the amino acids lysine (K) and leucine (L), and ODNIa, a single stranded } \\
\text { oligodeoxynucleotide with alternating sequences of the nucleic acids inosine and cytidine. A volume of } 0.5 \mathrm{~mL} \text { was administered } \\
\text { providing a dose of } 50 \mathrm{mg} \text { Ag85B-ESAT6 (antigen) and } 500 \mathrm{nmol} \mathrm{KLK}+20 \mathrm{nmol} \text { ODNIa (adjuvant) or } 0.5 \mathrm{~mL} \text { Tris buffer } \\
\text { (placebo). Each vial of placebo contents: sucrose }(50,000.0 \mathrm{mg} / \mathrm{mL}) \text {, soy lecithin }(2, I I 4.4 \mathrm{mg} / \mathrm{mL}) \text {, sodium cholate } 230.0 \mathrm{mg} / \mathrm{mL} \text { and } \\
\text { sodium chloride } 52.1 \mathrm{mg} / \mathrm{mL} \text {, which is exactly the same composition of RUTI vaccine, excepting the content of drug substance. }\end{array}$ \\
\hline Outcomes & 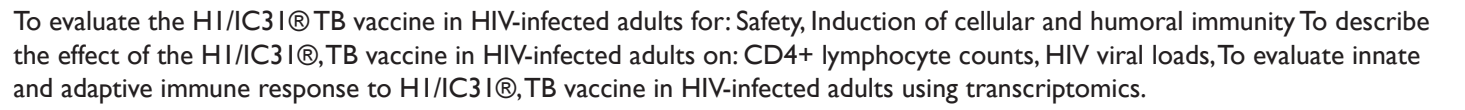 \\
\hline Notes & $\begin{array}{l}\text { The major deviation was recorded for one patient (HIV-negative group } 5 \mathrm{mg} \text { RUTI) at Day } 63 \text {, PBMC blood samples were } \\
\text { delivered to the laboratory with a delay of more than } 4 \text { hours. Additional samples had to be collected next day. Three patients } \\
\text { took theophylline in the pretreatment phase which was a prohibited concomitant medication according the exclusion criteria. }\end{array}$ \\
\hline
\end{tabular}

Table I 0 Risk of Bias (RUTI Nell et al., ${ }^{6}$

\begin{tabular}{|c|c|c|}
\hline Bias & Author's Judgment & Support for Judgment \\
\hline $\begin{array}{l}\text { Random } \\
\text { Sequence } \\
\text { Generation } \\
\text { (Selection Bias) }\end{array}$ & Low Risk & $\begin{array}{l}\text { The medication (RUTI vials) was prepared giving the RUTI or placebo after the random } \\
\text { attribution to a serial number generated using the RANDPLAN, a locally developed SAS } \\
\text { validated macro utilizing the PROC PLAN procedure in SAS. }\end{array}$ \\
\hline $\begin{array}{l}\text { Allocation } \\
\text { Concealment } \\
\text { (Selection Bias) }\end{array}$ & Low Risk & $\begin{array}{l}\text { The medication (RUTI vials) was prepared giving the RUTI or placebo after the random } \\
\text { attribution to a serial number generated using the RANDPLAN, a locally developed SAS } \\
\text { validated macro utilizing the PROC PLAN procedure in SAS }\end{array}$ \\
\hline $\begin{array}{l}\text { Blinding of } \\
\text { Participants } \\
\text { and Personnel } \\
\text { (performance } \\
\text { bias) }\end{array}$ & Low Risk & $\begin{array}{l}\text { The randomization list was sent to the persons responsible of the medication storage and } \\
\text { labelling and the rest of the personnel were kept blinded. }\end{array}$ \\
\hline $\begin{array}{l}\text { Blinding of } \\
\text { Outcome } \\
\text { Assessment } \\
\text { (detection bias) }\end{array}$ & Unclear Risk & $\begin{array}{l}\text { Medication was transferred to pharmacists at each trial site with the correspondent sealed } \\
\text { envelope labelled with the serial number containing information on the nature of the } \\
\text { medication inside. The envelopes were maintained in a locked secure place throughout the } \\
\text { whole study while still allowing access for emergency code breaking only. }\end{array}$ \\
\hline $\begin{array}{l}\text { Incomplete } \\
\text { Outcome Data } \\
\text { (attrition bias) }\end{array}$ & Unclear Risk & No Information Provided \\
\hline
\end{tabular}


Table Continued...

\begin{tabular}{lll}
\hline Bias & Author's Judgment & Support for Judgment \\
\hline $\begin{array}{l}\text { Selective } \\
\text { Reporting }\end{array}$ & Unclear Risk & No Information Provided \\
(reporting bias) & &
\end{tabular}

Competing Interests:The following statement was included in the cover letter: Jordi Picas and Merce 'Amat are employees of ArchivelFarma S.L., Pere-Joan Cardona is consultant of ArchivelFarma S.L., Andre S. Nell and Eva D'lom are employees of PAREXEL (South Africa)

Other bias Unclear Risk and PAREXEL International (Spain), respectively. Patrick Bouic is employee of Synexa Life Sciences (SouthAfrica), Ramon Bosser is employee of Janus Developments (Spain), and Montserrat Sabate' is an employee of TFS Develop (Spain). This does not alter the authors' adherence to all the PLOS ONE policies on sharing data and materials. Pere Joan Cardona is editor of PLOS ONE.

Table I I Characteristics of Excluded Studies: Justification for Excluded Studies

\begin{tabular}{ll}
\hline Study Identification & Reason for Exclusion \\
\hline ID93/GLA-SE & Evaluation of an adjuvanted vaccine against a clinical strain of M. Tuberculosis in a laboratory \\
M72/ASOI Day et al. & Patients were actively infected with TB at screening \\
M72/ASOI Idoko et al. & Vaccine is administered as a booster vaccine shortly after receiving BCG in infants \\
M72/ASOI Kumarasamy et al. & Not at least a Phase II study \\
M72/ASOI Montoya et al. & Dose-finding study, did not report efficacy or safety outcomes \\
\hline
\end{tabular}

Table I 2 Summary of Findings- Effectiveness Outcomes

\begin{tabular}{|c|c|c|c|c|c|c|}
\hline \multicolumn{7}{|c|}{ Experimental Vaccines Compared with Placebo for Tuberculosis } \\
\hline \multicolumn{7}{|c|}{$\begin{array}{l}\text { Patient or population: Patients in low to middle income countries where Tuberculosis is endemic } \\
\text { Settings: Clinical Trials site hospital or clinic } \\
\text { Intervention: Tuberculosis-targeted vaccine } \\
\text { Comparison: Placebo, equal amount of buffer }\end{array}$} \\
\hline Outcomes & $\begin{array}{l}\text { Illustrative } \\
\text { Assumed } \\
\text { Risk }\end{array}$ & $\begin{array}{l}\text { e comparative risks* }(95 \% \mathrm{Cl}) \\
\text { Corresponding Risk }\end{array}$ & $\begin{array}{l}\text { Relative } \\
\text { effect } \\
(95 \% \mathrm{Cl})\end{array}$ & $\begin{array}{l}\text { No of } \\
\text { participants } \\
\text { (studies) }\end{array}$ & $\begin{array}{l}\text { Quality of the } \\
\text { evidence (GRADE) }\end{array}$ & Comments \\
\hline $\begin{array}{l}\text { Positive Quantiferon } \\
\text { Conversion Rate Prior= } \\
\text { to study completion }\end{array}$ & $\begin{array}{l}10 \text { per } \\
1000\end{array}$ & I Per I000 (0 to 3) & $\begin{array}{l}\text { RR } \\
\mathbf{2 . 7 2}(0.94 \\
\text { to } 7.85)\end{array}$ & $3328(3)$ & $\oplus \oplus \oplus \ominus$ moderate & $\begin{array}{l}\text { QFT results study data was } \\
\text { unavailable for two studies. The } \\
\text { test was performed in both } \\
\text { cases, but was not reported. }\end{array}$ \\
\hline $\begin{array}{l}\text { Cytokine Positive } \\
\text { CD4 Positive T-Cells } \\
\text { Expressing IFN-y } \\
\text { Range: >350 cells per } \\
\mu \mathrm{L} \text { testing performed at } \\
\text { predetermined intervals } \\
\text { post-immunization to } \\
\text { determine immune } \\
\text { response }\end{array}$ & $\begin{array}{l}\text { The mean } \\
\text { I } 8 \% \text { cells } \\
\text { per } \mu \mathrm{L} \\
\text { ranged } \\
\text { across } \\
\text { control } \\
\text { groups } \\
\text { from } 0.02 \\
\text { to } 0.5 \% \\
\text { cells per } \mu \mathrm{L}\end{array}$ & $\begin{array}{l}\text { The mean } 1.02 \% \text { cells per } \mu \mathrm{L} \text { in } \\
\text { the intervention groups was } 0.75 \\
\text { to I.I5\% per } \mu \mathrm{L}\end{array}$ & & $4025(4)$ & $\oplus \oplus \oplus \ominus$ moderate & $\begin{array}{l}\text { Results were reported using } \\
\text { different scales so figures } \\
\text { needed t be adjusted to allow } \\
\text { for a comparison across } \\
\text { studies. }\end{array}$ \\
\hline
\end{tabular}

Table I 3 Summary of Findings Table-Safety Outcomes

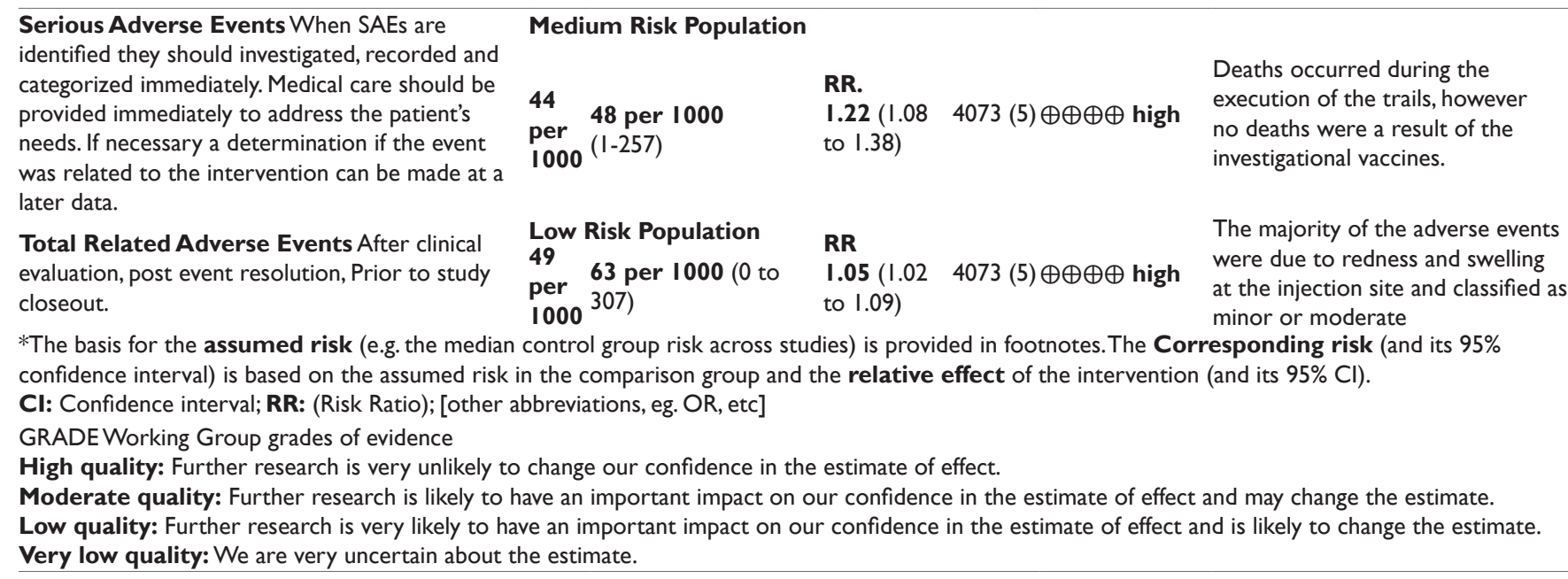


Table I 4 Efficacy and Outcomes

\begin{tabular}{|c|c|c|c|c|}
\hline Outcome or Subgroup & Studies & Participants & Statistical Method & Effect Estimate \\
\hline Positive Quantiferon Conversion Rate & 3 & 3328 & Risk Ratio (M-H, Random, 95\% Cl) & $2.72[0.94,7.85]$ \\
\hline $\begin{array}{l}\text { Cytokine Positive CD4 Positive T-Cells } \\
\text { Expressing IFN-y }\end{array}$ & 4 & 4025 & Std. Mean Difference (IV, Random, 95\% Cl) & $1.92[1.19,2.65]$ \\
\hline
\end{tabular}

Table I 5 Safety Outcomes Data

\begin{tabular}{|c|c|c|c|c|}
\hline Outcome or Subgroup & Studies & Participants & Statistical Method & Effect Estimate \\
\hline Serious Adverse Events & 5 & 4073 & Risk Ratio (M-H, Fixed, 95\% Cl) & $\mathrm{I} .22[\mathrm{I} .08, \mathrm{I} .38]$ \\
\hline Total Related Adverse Events & 5 & 4073 & Risk Ratio (M-H, Fixed, 95\% Cl) & $1.05[1.02,1.09]$ \\
\hline
\end{tabular}

Table 16 Baseline Characteristics Outcomes Data

\begin{tabular}{|c|c|c|c|c|}
\hline Outcome or Subgroup & Studies & Participants & Statistical Method & Effect Estimate \\
\hline Female Participant Allocation & 5 & 4073 & Risk Ratio (M-H, Random, 95\% Cl) & $\mathrm{I} .06[0.95, \mathrm{I} .18]$ \\
\hline HIV Positive Participants & 3 & 1020 & Risk Ratio (M-H, Random, 95\% Cl) & $2.02[0.14,28.19]$ \\
\hline Age $>18$ years & 3 & 792 & Risk Ratio (M-H, Fixed, 95\% Cl) & $\mathrm{I} .00[0.99, \mathrm{I} .0 \mathrm{I}]$ \\
\hline
\end{tabular}

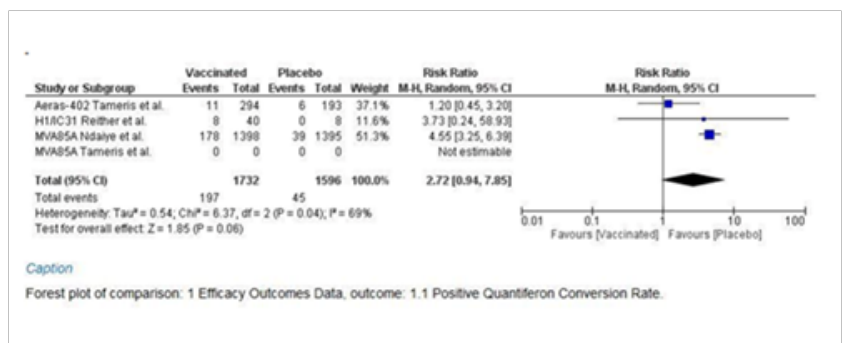

Figure I Efficacy outcome - Positive Quantiferon Conversion Rate.

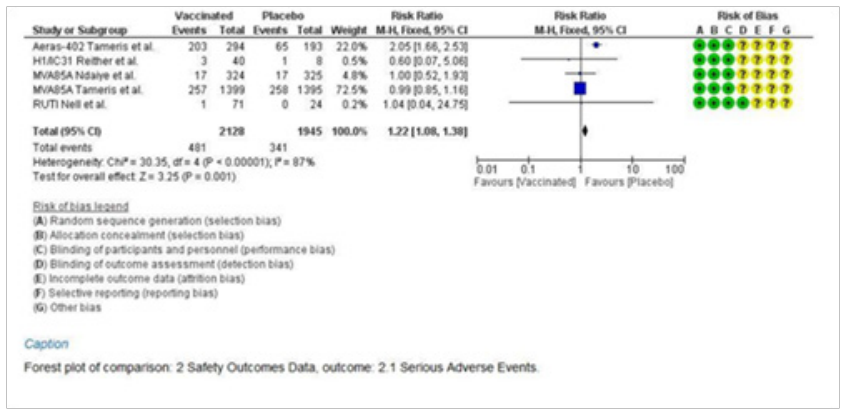

Figure 2 Safety Outcome - Serious Adverse Events.

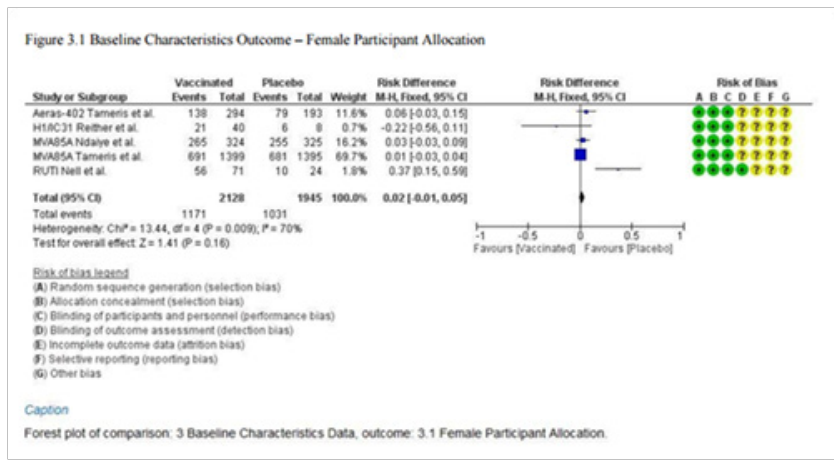

Figure 3 Baseline Characteristics Outcome - Female Participant Allocation.

\section{Conclusion}

There is promise that the vector types explored in this review possess potential vial delivery pathways for future vaccines in this area. These vaccines could be used as boosters to BCG in infants or as new interventions to improve responses in patients with co- morbidities closely associated with Tuberculosis, such as HIV and Meningitis. ${ }^{21-26}$ There is a case that the immune responses which were observed immediately after immunization could be sustained if dosages were increased at levels which maintain the safety profiles observed in these trials.

\section{Acknowledgements}

Dr Jeremy Howick for providing guidance on the design and planning necessary to execute this systematic review.

\section{Conflicts of interest}

Author declares there are no conflicts of interest.

\section{Funding}

None.

\section{References}

1. Plotkin SA, Orenstein WA, Offit PA. Tuberculosis Vaccines. Vaccines. 2013;789-811.

2. Ho MM, Southern J, Kang HN, et al. WHO informal consultation on standardization and evaluation of BCG Vaccines. Vaccine. 2010;28(43):6945-6950.

3. Tamerisa M, Hokeye DA, Ndubab V, et al. A double-blind, randomised, placebo-controlled, dose-finding trial of the novel tuberculosis vaccine AERAS-402, an adenovirus-vectored fusion protein, in healthy, BCGvaccinated infants. Vaccine. 2015;33(25):2944-2954.

4. Klaus R, Lynn K, Trevor B, et al. Safety and Immunogenicity of 50 H1/IC31H,an Adjuvanted TB Subunit Vaccine, in HIV-Infected Adults with CD4+ Lymphocyte Counts Greater than 350 cells $/ \mathrm{mm} 3$ :A Phase II, Multi-Centre, Double-Blind, Randomized, Placebo-Controlled Trial. PLos One . 2014;9(12):1-19.

5. Birahim PN, Friedrich T, Martin O, et al. Safety, immunogenicity, and efficacy of the candidate tuberculosis vaccine MVA85A in healthy adults infectedwithHIV-1: a randomised, placebo-controlled, phase 2 trial. Lancet Respir Med. 2015;3(3):190-200.

6. Archivel FSL. Clinical Trial to Investigate the Safety, Tolerability, and Immunogenicity of the Novel Antituberculous Vaccine RUTI ${ }^{\circledR}$ Following One Month of Isoniazid Treatment in Subjects With Latent Tuberculosis Infection. Clinical trails gov. 2010.

7. Michele DT, Mark H, Bernard SL, et al. Safety and efficacy of MVA85A, a new tuberculosis vaccine, in infants previously vaccinated with BCG: a randomised, placebo-controlled phase $2 \mathrm{~b}$ trial. Lancet. 2013;381(9871):1021-1028. 
8. Andre SN, Eva D'lom, Patrick B, et al. Safety, Tolerability, and Immunogenicity of the NovelAntituberculous Vaccine RUTI Randomized, Placebo-ControlledPhase II Clinical Trial in Patients with Latent Tuberculosis Infection. Plos One. 2014;9(2):e89612.

9. Behr MA. BCG-Different Strains, Different Vaccines? The Lancet Infectious Disease. 2002;2(2):86-92.

10. Delany I, Rappouli R, DeGregorio E. Vaccines for the 21 st Century. EMBO Mol Med. 2014;6(6):708-720.

11. Draper SJ, Heeney JL. Viruses as vaccine vectors for infectious diseases and cancer. Nat Rev Microbiol . 2010;8(1):62-73.

12. Guyatt GH, Oxman AD, Vist G, et al. GRADE guidelines: 4. Rating the quality of evidence--study limitations (risk ofbias). J Clin Epidemiol. 2011;64(4):407-415.

13. Higgins JP, Thompson SG, Deeks JJ, et al. Measuring inconsistency in meta-analyses. BMJ . 2003;327(7414):557-560.

14. Higgins JP, Thompson SG. Quantifying heterogeneity in a metaanalysis. Stat Med. 2002;21(11):1539-1558.

15. Higgins JPT, Deeks JJ, Altman DG. Special topics in statistics. Australian National University, Australia. 2011.

16. Higgins JPT, Green S. Cochrane Handbook for Systematic Reviews of Interventions. Australian National University, Australia. 2011.

17. Hokey DA, Wachholder R, Darrah PA, et al. A nonhuman primate toxicology and immunogenicity study evaluatingaerosol delivery of AERAS-402/Ad35 vaccine. Hum Vaccin Immunother. 2014;2:2199-2210.
18. Kagina BM, Charles SW, Maia L. Safety of licensed vaccines in HIVinfected persons: a systematic reviewprotocol. Syst Rev. 2014;3: 101.

19. Orme IM. Development of new vaccines and drugs for TB: limitations and potential strategic errors. Future Microbiol . 2011;6:161-177.

20. Rao JN, Scott AJ. A simple method for the analysis of clustered binary data. Biometrics. 1992;48(2):577-585.

21. Sterne JA, Egger M. Funnel plots for detecting bias in meta-analysis: guidelines on choice of axis. J Clin Epidemiol. 2001;54(10):1046-1055.

22. Sterne JA, Sutton AJ, Ioannidis JP, et al. Recommendations for examining and interpreting funnel plot asymmetry in meta-analyses of randomised controlled trials. BMJ . 2011;343:4002.

23. Tameris M, McShane H, McClain JB, et al. Lessons learnt from the first efficacy trial of a new infanttuberculosis vaccine since BCG. Tuberculosis. 2013;93(2):143-149.

24. WHO .Library Cataloguing-In-Publication Data. World Health Organization. 2015.

25. WHO. Revised BCG Vaccination Guidelines for Infants at risk for HIV Infection. Wkly Epidemiol Rec. 2007;82(21):193-196.

26. Young DB, Graham RS. Vaccination. Tuberculosis Vaccines. 2002;62(1):73-86. 